\title{
Order of the International Ban and Albania's Agreements with Other Countries
}

\author{
Ph.D Nikolin Hasani \\ University "Ismail Qemali" Vlore \\ Faculty of Human Sciences, Department of Law
}

\begin{abstract}
Higher stage of cooperation in criminal matters between European states is undisputed the adoption of the International Order of Prohibition (UEN) which was materialized by means of Decision Framework Constitution Nr.5841 , dated June 13, 2002. This decision was endorsed by the EU Council and published in its official bulletin on June 18, 2002. Among the EU member states this order replaces classical Extradition procedure, except when some member states have declared that they will continue to implement the conventions of Extradition. ${ }^{2}$ From this moment the extradition procedures applied within the EU, are without legal force. The aim of this paper is to present a brief analyse of Albania's agreements with other countries, pointing out specific aims of them, specific conditions of implementations according the specifical need for judicial cooperation between Albania and each of these countries.
\end{abstract}

Key words: international ban order, international cooperation, judicial cooperation.

\section{Order of the International ban}

Extradition procedure has been replaced with a more flexible, simpler, like most of arrest procedure applied by the relevant authorities in a member country. It should be noted that in essence the procedure and scope of the UEN is similar on Extradition, but the first were eliminated administrative bureaucracies making more efficient this instrument, merging the boundaries concerning the submission of the defendant by a Member State in another one .

UEN responds the best to primary objective of the Treaty of Amsterdam. So starting from 1 January 2004 between Member States of the EU are not applied to bilateral or multilateral international agreements on Extradition, that are:

European Convention on Extradition, Paris, 1957, with two additional protocols.

Convention on the simplification of extradition procedures between EU countries, in March 1995.

EU Convention on Extradition, in September 1996, etc

\section{Agreement between Albania and other countries}

Albania has signed several agreements with different countries with the sole purpose to fight crime, to carry out the punishment of prisoners and detainees, but also to influence the reintegration, socialization and rehabilitation with the family, relatives enabling their transfer from prisons or detention abroad of detention in prisons in the country. Some of the agreements have been signed with Greece, the Kingdom of Belgium, the UK, etc., for example:

Agreement between the Government of the Republic of Albania and the Council of Ministers of Bosnia and Herzegovina on cooperation in combating crime, especially terrorism, illegal drug trafficking and organized crime, signed on 24.03.2009, entered into force on 04.03.2010.

\footnotetext{
1 Council Framework Decision 2002/584/JHA of 13 June 2002

2 European Order of Prohibition - Valbona Ndrepepaj.
} 
Agreement on cooperation between the Council of Ministers of the Republic of Albania and the Republic of Bulgaria in the fight against trafficking, organized crime, signed on 01.29.2007, entered into force at 4:10. 2007.

Convention between the People's Republic of Albania and the Czechoslovak Republic on Legal Helpers award for civil, family and criminal matters, signed on 16.01.1959, entered into force on 28.05.1960.

Protocol for Cooperation in the field of justice between the Ministry of Justice of the Republic of Albania and the Ministry of Justice of the Arab Republic of Egypt, signed on 15.12.1994, entered into force on the date of signature.

Agreement between the Republic of Albania and the Arab Republic of Egypt on extradition, signed on 02.04.2002, entered into force on 26.07.2004.

Agreement between the Government of the Republic of Albania and the Republic of Latvia on cooperation in the fight against organized crime, illegal trafficking of narcotic drugs, psychotropic substances and precursors of other crimes, signed on 16.12.2009, entered into force on 22.07.2010."?

\subsection{Convention between the Republic of Albania and Republic of Greece on mutual enforcement of court decisions in criminal matters ${ }^{1}$}

The Republic of Albania and the Republic of Greece, desiring to expand the juridical relations between the two countries and advance cooperation in the judicial sector, and to facilitate the social reinsertion of persons who have been convicted, remain agree to enter into this Convention regarding the implementation of mutual judicial decisions in criminal matters and for this purpose appointed as the Almighty: Prime Minister of Albania and Prime Minister of Greece, who exchanged the relevant documents which were confirmed as they were designed as needed, put the following provisions: Transfer execution and results.

The transfer request

Article 6

If the state of the sentence deems that are fulfilled, under this Convention, the conditions for the transfer of execution may lead the request to the execution state to transfer the execution of a sentence or measure involving deprivation of liberty has been taken

\section{Admission: Article 7}

On the basis of the application provided for in Article 6, which is associated in the documents referred to in Article 13, the state of implementation of the sentence informs state the date and place of the transfer or delivery of prisoners. From the time of delivery of execution of actions in state suspended.

Article 8

When the petition, which is provided for in Article 6 is accepted, the court replaces the state of implementation of the sentence imposed in the State of with a punishment or an analog measure of deprivation of liberty responds to its nature and duration. However, if the penalty or measure of deprivation of liberty for the type or duration of it is incompatible legislation of the State of enforcement, the court of the latter adapts it to the punishment or measure provided for by the law of opportunities for nature or its duration, with the decision for implementation. Despite this state of implementation can not return a sentence of detention in a punishment of liberty other than if its legislation does not provide for punishment of imprisonment for the violation in question. In any case, the state of implementation can not make an assessment of the evidence underlying the decision taken in the State of.

Ways of implementation of decisions including the bail, set by the legislation of the state of implementation.

\footnotetext{
${ }^{1}$ The decision of the Constitutional Court No. 6, dated 30.4.2004
} 
Transfer shall in no case be brought worsening the position of the convicted person.

Duration of the arrest in the state of conviction shall be calculated entirely on the extension of the sentence or measure to be served on the state of implementation.

Results of implementation

Article 9

Subject to the provisions of Article 8, the decision of the State of sentencing, if the transfer of the application, the same legal results in the state of implementation of those decisions on criminal matters in the latter.

If the convicted person evades enforcement in the state of implementation class, state of the sentence takes its right to enforce the sentence for the remainder.

The right of enforcement of state definitely cease to exist if the inmate was convicted or acquitted definitely.

\section{Agreement between the Republic of Albania and the Kingdom of Belgium "On the transfer of sentenced persons ${ }^{1 "}$}

The Republic of Albania and the Kingdom of Belgium, interested in boosting relations of friendship and cooperation between the two countries and in particular the strengthening of legal cooperation; Desiring to resolve issues by mutual agreement on the transfer of sentenced persons, while respecting the fundamental principles of human rights universally accepted; Desiring to allow persons convicted to serve their period of detention in the country of which they are citizens, in order to facilitate their social reintegration; located in this spirit, to maintain the highest level possible, in addition to the terms and conditions of the European Convention on the Transfer of Sentenced Persons, signed in Strasbourg on March 21, 1983, the mutual cooperation in the transfer of sentenced persons imprisonment, have agreed as follows:

\section{Article 1}

General provision and expressions used in this Agreement shall be interpreted within the meaning of the European Convention on the Transfer of Sentenced Persons, signed in Strasbourg on March 21, 1983.

Article 2

Convicted persons are subject to an expulsion or deportation order

At the request of the sentencing State, the state executive, according to the provisions of this article may agree on the transfer of a sentenced person without the consent of that person, when the sentence given to the latter, or an administrative decision following of that sentence, includes an expulsion or deportation order or any other measure as a result of which one person would not be allowed to remain in the territory of the sentencing state when he or she is released from prison.

Executing country does not give his consent for the purposes of paragraph 1 before having taken into consideration the opinion of the convicted person.

For the purposes of this Article, state sentencing State gives performers a declaration containing the opinion of the sentenced person in connection with the transfer of his or her proposed; and a copy of the expulsion or deportation order or any other order, which has the effect that the convicted person not allowed to stay in the territory of the sentencing State when he or she is released from prison.

Any person transferred under the provisions of this Article shall not prosecuted, punished or arrested, in order to implement a decision or order of detention for any offense committed prior to the transfer of his or her different from that for which it was given punishment It should apply, he or she does not even restrict the freedom of his or her personal information for any other reason, except when the sentencing state authorizes: a request for authorization, accompanied by all relevant documents and a record legal any statement made by the convicted person. 
The authorization is given when the offense for which requested this authorization shall be subject to extradition under the law of the sentencing State or when extradition would be excluded only because of the sentence and the convicted person has had the opportunity to leave the territory of executing country state, has not done so within 45 days of the release of his or her final, or if he or she has returned to that territory after leaving it. Executing country may take the measures necessary under its law, including proceedings in absentia to prevent any legal effects of lapse of time.

\section{Extradition agreement between Albania and the UK ${ }^{1}$}

Binding agreement to transfer the prisoners would allow the British government to transfer legitimate Albanian citizens from prisons in the United Kingdom for their country, to carry out the rest of the sentence. Also, the British prisoners in Albania will be transferred to prisons in the United Kingdom. In both cases, the prisoner will carry out the punishment imposed by the court. But the transfer to a prison in their country will increase the welfare of prisoners and eventual reintegration into society, for example by allowing a greater contact with their family. This is the first bilateral agreement of the UK for the transfer of prisoners which offers a compulsory transfer outside the European Union, as well as a very positive development in relations between Britain and Albania.

\section{Transfer of sentenced persons between the Republic of Albania and Italy}

In support of the Council of Europe Convention "On the Transfer of Sentenced Persons", "Republic of Albania ratified by Law no. 8499, dated 10.06.1999, "the Additional Agreement to the Council of Europe Convention on the transfer of sentenced persons" between the Republic of Albania and the Republic of Italy, ratified by Law no. 9169, dated 22.01.2004, Articles 512-518 of the Criminal Procedure Code, the Law on the Prosecutor's Office;

In order:

Increasing efficiency in jurisdictional cooperation as regards the transfer of prisoners between the Republic of Italy and Albania;

Regulation of the unification of the procedure transfer of prisoners, Albanian citizens, who suffer the punishment of imprisonment on the basis of a court decision final, given by the Italian judicial authorities;

Defenition of modalities for the implementation of this form of co-operation.

\section{Conclusions}

The literature shows that the Albanian legislation in this area has undergone developments and continuous improvements, toward international standards accepted by responding to dynamic needs and growing demands for change and reform in the system of penitentiary and suffering sentence, and aiming to guarantee the rights and fundamental freedoms.

Albania's commitment to aligning with the EU legislation and to implement international standards, shows the serious and concrete steps to achieve these objectives. It is worth to highlight that the legal framework, the Constitution, the Criminal Code, Code of Criminal Procedure, the Law "On the execution of criminal judgments", the law "On the rights and treatment of prisoners" and other laws and regulations Main this field have brought development and continuous improvement, both in the criminal justice system in general, as well as the transfer institution, implementing social rehabilitation programs, aimed at modifying the criminal behavior and training in social skills.

\section{References}

[1] Marrëveshje ekstradimi ndërmjet Shqipërisë dhe Britanisë së Madhe, nënshkruar më 22 korrik 1926.

[2] Assenov and Others v. Bulgaria, vendim i datës 28 tetor 1998, Raporte të vendimeve dhe gjykimeve 1998-VIII, fq. 3296.

1 Extradition agreement between Albania and the United Kingdom, signed on July 22, 1926. 
[3] Hoxha,A.:Ekstradimi sipas instrumentave ligjore të BE. Ngjashmëritë dhe ndryshimet me instrumentat e Këshillit të Europës.Tiranë 2010.

[4] Hysi,V. 2009. Penologjia.Tiranë 2009.

[5] Kodi Penal i Republikës së Shqipërise Miratuar me ligjin nr.7895, datë 27.1.1995. Botim i Qendrës së Botimeve Zyrtare.

[6] Konventa midis Republikës Popullore të Shqipërisë dhe Republikës Çekosllovake mbi dhënien e ndihës juridike për çështjet civile, familjare dhe penale, nënshkruar më 16.01.1959, hyrë në fuqi më 28.05.1960.

[7] Marrëveshje ekstradimi ndërmjet Shqipërisë dhe Britanisë së Madhe, nënshkruar më 22 korrik 1926.

[8] Ligji Nr.8328, datë 16.4.1998 "Ligji Nr.8328, datë 16.4.1998 "Për të drejtat dhe trajtimin e të dënuarve me burgim dhe të paraburgosur".

[9] Ligji Nr. Nr.8331, Datë 21.4.1998 "Për Ekzekutimin e Vendimeve Penale".

[10] Ligj Nr.8499, date 10.6.1999 FZ. 22-1999. "Ratifikimi i Konvëntës së Këshillit të Europës", "Për Transferimin e Personave Dënuar".

[11] Council Framework Decision 2002/584/JHA of 13 June 2002.

[12] Council Frameëork Decision 2002/584/JHA of 13 June 2002.

[13] Vendimi i Gjykatës Kushtetuese Nr.6, datë 30.4.2004

[14] Ligji Nr.9911, datë 5.5.2008 "Për disa ndryshime në ligjin nr.7905 datë: 21.3.1995 "Kodi i Proçedurës Penale i Republikës së Shqipërisë" i ndryshuar pas Tetor 2004.

[15] Ligj Nr.10 378, datë 24.2.2011. Marrëveshje midis Republikës së Shqipërisë dhe Mbretërisë së Belgjikës "Për transferimin e personave të dënuar". 